\title{
The use of multimodal low-opioid anesthesia for coronary artery bypass grafting surgery in conditions of artificial blood circulation
}

\author{
Oleg Loskutov${ }^{1}$, Taisiia Danchyna ${ }^{1}$, Dmitryi Dzuba ${ }^{1}$, Oleksandr Druzina ${ }^{2}$
}

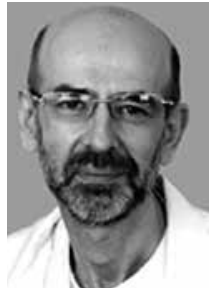

${ }^{1}$ Department of Anesthesiology and Intensive Care, Shupyk National Medical Academy of Postgraduate Education, Kyiv, Ukraine

${ }^{2}$ Department of Anaesthesiology and Perfusiology, SE "Heart Institute" of $\mathrm{MOH}$, Kyiv, Ukraine

Kardiochir Torakochir Pol 2020; 17 (3): 111-116

\begin{abstract}
Introduction: Cardiovascular diseases (CVD) are the main cause of death worldwide, and according to experts, they will continue to dominate the structure of global mortality.

Aim: The effectiveness of the multimodal low-opioid anesthesia technique in performing coronary artery bypass graft operations with artificial blood circulation.

Material and methods: Ninety-six patients aged $61.8 \pm 10.4$ years underwent coronary artery bypass grafting under artificial blood circulation. Group I: propofol, sevoflurane, fentanyl, pipecuronium bromide (standard doses). Group II: dexketoprofen trometamol (50 mg), intravenous lidocaine $(1 \%-1 \mathrm{mg} / \mathrm{kg}$ bolus) and continuous lidocaine infusion (1.5-2 mg/kg/h), propofol, ketamine $(0.5 \mathrm{mg} / \mathrm{kg})$, magnesia sulfate, minimal doses of fentanyl.

Results: Average duration of anesthesia $-257.4 \pm 19.1 \mathrm{~min}$; as sisted blood circulation $-55 \pm 10 \mathrm{~min}$. Mean dose of fentanyl in group I - $4.66 \pm 1.58 \mu \mathrm{g} / \mathrm{kg} / \mathrm{h}$, in group II $-1.29 \pm 0.32 \mu \mathrm{g} / \mathrm{kg} / \mathrm{h}$. Standard lab values and stress hormonal changes were within the normal range (mean cortisol: $479.3 \pm 26.4 \mathrm{nmol} / \mathrm{l}$, lactate $1.61 \pm 0.2 \mathrm{mmol} / \mathrm{l}$, glucose $6.42 \pm 0.9 \mathrm{mmol} / \mathrm{l})$. Changes in heart rate within group I had a significant amplitude of dynamics, while in group II, these values were relatively at the same level throughout the entire anesthetic provision. Mean arterial pressure changes in group I were characterized by a significant reduction at the stage of induction, support and sternum reduction, whereas in group II it was relatively at the same level during the entire anesthetic management and significantly differed from baseline only at the stage of induction.

Conclusions: Multimodal low-opioid anesthesia during coronary artery bypass surgery with artificial blood circulation allows one to ensure adequate analgesia and avoid the intraoperative usage of routine doses of fentanyl, as indicated by the absence of hemodynamic and endocrine-metabolic changes.
\end{abstract}

Key words: anesthesia, cardiac, intravenous lidocaine, opioidfree, low-opioid.

\section{Streszczenie}

Wprowadzenie: Choroby sercowo-naczyniowe (CVD) stanowią główną przyczynę zgonów na świecie i według ekspertów nadal będą przeważać w strukturze globalnej śmiertelności.

Cel pracy: Ocena skuteczności złożonego znieczulenia niskoopioidowego podczas operacji pomostowania tętnic wieńcowych w warunkach krążenia pozaustrojowego.

Materiał i metody: U 96 pacjentów w wieku 61,8 $\pm 10,4$ roku przeprowadzono pomostowanie tętnic wieńcowych z wykorzystaniem krążenia pozaustrojowego. Grupa I: propofol, sewofluran, fentanyl, bromek pipekuronium (dawki standardowe). Grupa II: trometamol deksketoprofenu (50 mg), lidokaina dożylnie $(1 \%$ - bolus $1 \mathrm{mg} / \mathrm{kg})$ i lidokaina w ciągłym wlewie (1,5-2 mg/kg/h), propofol, ketamina (0,5 mg/kg), siarczan magnezu, fentanyl w minimalnych dawkach.

Wyniki: Średni czas trwania znieczulenia - 257,4 $\pm 19,1 \mathrm{~min}$; wspomaganie krążenia - $55 \pm 10$ min. Średnia dawka fentanylu w grupie I - 4,66 $\pm 1,58 \mu \mathrm{g} / \mathrm{kg} / \mathrm{h}$, w grupie $I I-1,29 \pm 0,32 \mu \mathrm{g} / \mathrm{kg} / \mathrm{h}$. Standardowe parametry laboratoryjne i zmiany w stężeniu hormonów stresu mieściły się w zakresie normy (średnie stężenie kortyzolu: 479,3 $\pm 26,4 \mathrm{nmol} / \mathrm{l}$, mleczan 1,61 $\pm 0,2 \mathrm{mmol} / \mathrm{l}$, glukoza $6,42 \pm 0,9 \mathrm{mmol} / \mathrm{l})$. Zmiany częstości akcji serca w grupie I charakteryzowały się znaczną amplitudą, natomiast w grupie II wartości utrzymywały się na relatywnie tym samym poziomie przez cały okres znieczulenia. Średnie zmiany ciśnienia tętniczego $\mathrm{w}$ grupie I były znamiennie mniejsze podczas indukcji, podtrzymania i zamknięcia mostka, natomiast w grupie II utrzymywały się na tym samym poziomie przez całe znieczulenie i różniły się znamiennie od wartości wyjściowych wyłącznie na etapie indukcji.

Wnioski: Złożone znieczulenie niskoopioidowe podczas pomostowania tętnic wieńcowych z wykorzystaniem krążenia pozaustrojowego umożliwia właściwą analgezję i pozwala uniknąć śródoperacyjnego podawania rutynowych dawek fentanylu, czego potwierdzeniem jest brak zmian hemodynamicznych i endokrynologiczno-metabolicznych.

Słowa kluczowe: znieczulenie, kardiologiczne, dożylna lidokaina, bezopioidowe, niskoopioidowe.

Address for correspondence: PhD Student, Taisiia Danchyna MD, Department of Anesthesiology and Intensive Care, Shupyk National Medical Academy of Postgraduate Education, Kyiv, Ukraine, phone: +38 0954993743, e-mail: tdanchynamd@gmail.com

Received: 24.04.2020, accepted: 1.08.2020. 


\section{Introduction}

Cardiovascular diseases (CVD) are the main causes of death worldwide. According to experts, CVD will continue to dominate global mortality structure. In 2016, about 1/3 of all deaths worldwide were caused by CVD [1]. At the same time, coronary heart disease (CHD) was the main death cause associated with CVD. CHD has been one of the leading causes of loss in living years for more than a decade. This underscores the shift of the global disease burden from infectious to chronic diseases [2].

A similar trend was indicated by World Health Organization reports, which state that in recent years the predominance of chronic diseases has been noted as the main factor in overall global mortality [2]. CVD is by far the largest global mortality source and will continue to dominate trends in overall mortality in future.

Disability due to coronary heart disease, the treatment complexity and patient's rehabilitation with myocardial ischemia lead to huge economic losses. The cost of only primary hospitalization for myocardial infarction varies in different countries from 1.605 to 9.196 thousand USD [3].

In terms of delayed favorable results, coronary artery bypass grafting (CABG) is one of the effective and longterm methods of CHD treatment [3]. It should be noted that such operations require the creation of optimal conditions for adequate systemic hemodynamics functioning and early postoperative ( $\mathrm{p} / \mathrm{o})$ patients' rehabilitation.

Despite indication methods improvement in the main vital body regulation functions, and low rates of hospital mortality $(0.4-2.4 \%)$, the complications scale in the perioperative period during CABG remains significant [3], which largely concerns the anesthetic support adequacy.

Opioid analgesics are traditionally used for cardiac surgery. However, this use is associated with well-known

Table I. Clinical characteristics of the examined patients $(n=96)$

\begin{tabular}{lc} 
Indicator & Value \\
Sex $(\mathrm{w} / \mathrm{m})$ & $16 / 80$ \\
\hline Weight $[\mathrm{kg}]$ & $56-132(85.61 \pm 14.2)$ \\
\hline Age [years] & $28-78(61.8 \pm 10.4)$ \\
\hline Accompanying pathology: & $96(100 \%)$ \\
\hline AH & $32(33.3 \%)$ \\
\hline DM & $48(49.9 \%)$ \\
\hline Smoking & $35(36.5 \%)$ \\
\hline History of MI & $14(14.6 \%)$ \\
\hline History of stenting & $1(1.04 \%)$ \\
\hline History of CABG & $9(9.36 \%)$ \\
\hline History of CRF & $11(11.4 \%)$ \\
\hline CV pathology in anamnesis & $2.8 \pm 1.6$ \\
\hline Number of affected coronary vessels: & $71(73.8 \%)$ \\
\hline Average for the group & \\
\hline$>3$ &
\end{tabular}

$\mathrm{AH}$ - arterial hypertension, DM - diabetes mellitus, $\mathrm{MI}$ - myocardial infarction, CABG - coronary artery bypass grafting, CRF - chronic renal failure,

$\mathrm{CV}$ - cerebrovascular. side effects: p/o respiratory depression, development of $\mathrm{p} / \mathrm{o}$ nausea, vomiting, retention of serum, prolongation of intestinal paresis, etc. In addition, the use of standard routine doses of opioids may be associated with p/o hyperalgesia and increased need for pain management, which often leads to chronic pain syndrome formation [4].

It is obvious that anesthesia in cardiac surgery should provide the maximum level of "analgesic comfort", an adequate hypnotic effect with minimal side effects on systemic hemodynamics and coronary blood flow, while at the same time providing the possibility of early p/o rehabilitation [5].

\section{Aim}

The purpose of this work was to evaluate the effectiveness of the multimodal low-opioid anesthesia technique in performing coronary artery bypass graft operations with artificial blood circulation.

\section{Material and methods}

Ninety-six patients were the object of this single-centered study. On the basis of the state institution Heart Institute Ministry of Health of Ukraine c. Kyiv, Ukraine, planned CABG was performed under the artificial blood circulation $(A B C)$. The protocol of the study was approved by the state institution Heart Institute Ministry of Health of Ukraine ethics committee. Patients gave their oral and written consent to participate in the study.

The clinical characteristics of the examined patients are presented in Table I.

The age of patients ranged from 28 to 78 years (mean: $61.8 \pm 10.4$ years). The average weight was $85.61 \pm 14.2 \mathrm{~kg}$ (from 56 to $132 \mathrm{~kg}$ ) (Table I). We selected patients whose somatic condition corresponded to $3-5$ points according to the European system surgery risk assessment in patients with CHD.

The distribution of patients by functional class (FC) according to the New York Cardiology Association functional classification (NYHA Classification): 72 (74.9\%) patients had II FC by NYHA, 24 (24.9\%) patients had III FC by NYHA.

Concomitant arterial hypertension was determined in all examined patients. The mean daily BPs/BPd (systolic blood pressure/diastolic blood pressure) was $143.5 \pm 22.9$ / $101.5 \pm 15.3 \mathrm{~mm} \mathrm{Hg}$. In 8 patients (8.32\% of cases), CHD was diagnosed 5 or more years before admission to the clinic. At admission, 68 (70.7\%) patients had functional class II heart failure according to T. Killip.

Preoperative combined antihypertensive therapy was continued until the day of elective surgery.

According to the anesthetic support scheme, all patients were divided into two groups.

The first group (50 patients) received a "standard" method of anesthesia, which included the combination of propofol with sevoflurane, fentanyl and pipecuronium bromide. In the second group (46 patients), a multimodal low-opioid anesthesia scheme was used with a combination of dexketoprofen trometamol, intravenous (IV) lidocaine, propofol, ketamine, magnesia sulfate and minimal doses of fentanyl. 
In the first group $(n=50)$, induction consisted of propofol administration (IV) at the dose of $1.54 \pm 0.1 \mathrm{mg} / \mathrm{kg}$, which was administered $40 \mathrm{mg}$ at intervals of $10-15 \mathrm{~s}$. After the introduction of hypnotics, all patients received fentanyl in the dose of $1-1.5 \mu \mathrm{g} / \mathrm{kg}$. After achieving an adequate level of anesthesia, muscle relaxation was achieved by IV administration of pipecuronium bromide at the dose of $0.1 \mathrm{mg} / \mathrm{kg}$, followed by tracheal intubation. Maintenance of anesthesia in group I was provided by inhalation of the minimum alveolar concentration (MAC) of sevoflurane $1.9 \pm 0.6$, focused on the indicators of the bispectral index (BIS) and maintaining them within 40-50\%. In this case, the electroencephalogram was registered in the frontal leads according to the scheme recommended by the manufacturer (Aspect Medical System Inc, USA), followed by the calculation of BIS (version 3.1). Maintenance of analgesia during surgery was performed by administration of fentanyl at a dose of $4.66 \pm 1.58 \mu \mathrm{g} / \mathrm{kg} / \mathrm{h}$.

In the second group $(n=46)$, dexketoprofen trometamol - $50 \mathrm{mg}$ (IV) was administered to patients prior to anesthesia. Induction included IV propofol at the dose of 1.52 $\pm 0.1 \mathrm{mg} / \mathrm{kg}$, which was administered at $40 \mathrm{mg}$ intervals of $10-15 \mathrm{~s}$, fentanyl at the dose of $1 \mu \mathrm{g} / \mathrm{kg}$ and lidocaine $1 \%-$ $1 \mathrm{mg} / \mathrm{kg}$ bolus. Muscle relaxation was achieved by IV administration of pipecuronium bromide at the dose of $0.1 \mathrm{mg} / \mathrm{kg}$, followed by tracheal intubation. Maintenance of anesthesia in group II included sevoflurane inhalation $(1.7 \pm 0.2 \mathrm{MAC})$ and continuous lidocaine infusion at the rate of $1.5-2 \mathrm{mg} / \mathrm{kg} / \mathrm{h}$. Lidocaine infusion was continued throughout the operation until the patient was admitted to the intensive care unit. Before the start of surgery (before incision), group II patients received subnarcotic dose of ketamine IV $(0.5 \mathrm{mg} / \mathrm{kg})$. The average dose of fentanyl that was used in patients with group II for the entire period of anesthetic support was 1.29 $\pm 0.32 \mu \mathrm{g} / \mathrm{kg} / \mathrm{h}$.

In both groups, artificial ventilation was performed with an air-oxygen mixture $\left(\mathrm{FiO}_{2}=50 \%\right)$ in the normal ventilation mode (flow of $2 \mathrm{l} / \mathrm{min}$ ). Artificial blood circulation was performed in moderate hypothermia conditions $\left(+32^{\circ} \mathrm{C}\right)$. The heart-lung machine performance during perfusion was $2.5 \mathrm{l} / \mathrm{min} / \mathrm{m}^{2}$.

To protect the myocardium at the main stage of the operation, artificial electrical heart fibrillation was used, which was created by a low-voltage generator (current frequency
- $50 \mathrm{~Hz}$, voltage - $12 \mathrm{~V}$, current - $25 \mathrm{~mA}$ ). In this case, the coronary vessels were perfused naturally with blood from the oxygenator of the artificial blood circulation apparatus.

During the course of anesthetic support, all patients underwent routine determination of the acid-base and gas composition of their blood.

$\mathrm{P} / \mathrm{O}$ intensive therapy in the early period was usually aimed at: correcting adequate hemo- and hydrobalance; acid-base and electrolyte balance; infectious complications prevention in both groups.

Analgesics prescribed in the early p/o period in the first group were opioid analgesics (10 mg of 1\% morphine hydrochloride). $\mathrm{P} / \mathrm{o}$ analgesia in patients of the second group was provided by the preparation of nonsteroidal anti-inflammatory drugs (dexketoprofen trometamol, $50 \mathrm{mg}$ every 6-8 hours for 2 days, paracetamol 1 g 2-4 times a day, and a prolonged infusion of lidocaine for the first 2:00 p/o period of $1.5-2 \mathrm{mg} / \mathrm{kg} / \mathrm{h}$ ).

\section{Compliance with ethical standards}

The study was done according to the main directions of scientific and experimental work of the P. L. Shupyk National Medical Academy of Postgraduate Education Department of Anesthesiology and Intensive Care: “Development of Organizational and Clinical Aspects of Improving Patients' Safety in Anesthesiology and Intensive Care" (State registration number: 0114U002223).

\section{Statistical analysis}

The results were analyzed on a personal computer using the Excel 2010 and Statistica 6 application programs. The reliability of statistical indicators was determined by Student's $t$-test. Nonparametric Mann-Whitney $U$ test was used in absence of normal distribution. Statistically significant differences were considered at the level of $p<0.05$.

\section{Results}

The results of comparing the effect of two anesthetic maintenance schemes on the dynamics of hemodynamic parameters and BIS are shown in Table II.

According to the results of our study, patients of both groups at the stage of induction into anesthesia had a significant decrease in heart rate $(H R)$ relative to base-

Table II. Dynamics of hemodynamic parameters at the stages of anesthesia using various schemes of anesthetic support, \% of the initial level $(n=96)$

\begin{tabular}{|c|c|c|c|c|c|c|c|c|}
\hline \multirow[t]{2}{*}{ Indicators } & \multicolumn{4}{|c|}{ Group I $(n=50)$} & \multicolumn{4}{|c|}{ Group II $(n=46)$} \\
\hline & Induction & Intubation & Maintenance & $\begin{array}{l}\text { The reduction } \\
\text { of the sternum }\end{array}$ & Induction & Intubation & Maintenance & $\begin{array}{l}\text { The reduction } \\
\text { of the sternum }\end{array}$ \\
\hline$\Delta \mathrm{HR}(\%)$ & $-26.5^{\star}$ & $-4.8^{\dagger}$ & $-25.6^{\star \dagger}$ & $-1.1 \dagger$ & $-16.9^{\star}$ & $-16.0^{* \wedge}$ & $-16.6^{*}$ & -10.3 \\
\hline$\triangle \mathrm{MAP}(\%)$ & -32.4 & $-8.3^{\dagger}$ & $-27.5^{\star \dagger}$ & $-21.1^{*}$ & $-8.0^{* \wedge}$ & -1.0 & $-5.2^{\star \wedge}$ & $-3.3^{\wedge}$ \\
\hline$\Delta \mathrm{PPI}(\%)$ & $85.7^{\star}$ & $85.7^{\star}$ & $128.6^{\star \dagger}$ & $42.9^{* \dagger}$ & $114.3^{\star \wedge}$ & $100.0^{\star}$ & $200.0^{* \wedge \dagger}$ & $57.1^{\star \dagger}$ \\
\hline$\Delta \mathrm{BIS}(\%)$ & $-51.3^{*}$ & $-50.1^{*}$ & $-52.5^{\star}$ & $-52.4^{*}$ & $-50.9^{*}$ & $-52.2^{*}$ & $-48.9^{*}$ & $-50.8^{\star}$ \\
\hline
\end{tabular}

${ }^{\dagger} P<0.05$ compared to the previous value, $\wedge p<0.05$ compared between the study groups, ${ }^{\star} p<0.05$ compared to the original values, MAP - mean arterial pressure, $\mathrm{HR}$ - heart rate, PPI - peripheral perfusion index, BIS - bispectral index. 


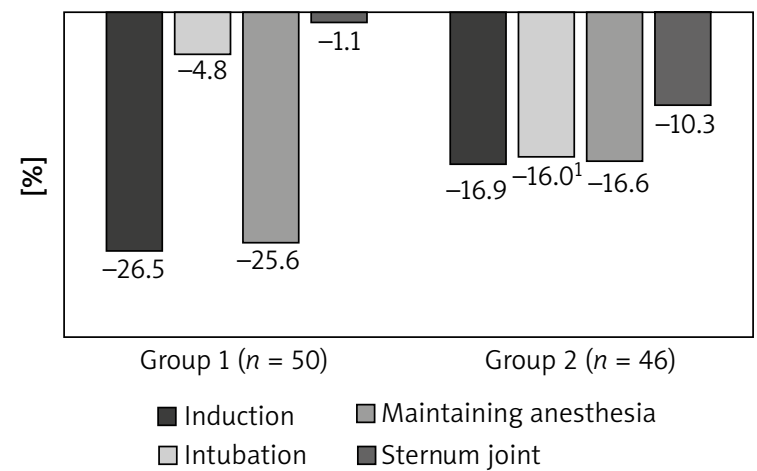

Figure 1. Dynamics of HR at the stages of anesthesia using various schemes of anesthetic support, percentage of the initial level ${ }^{1} p=0.037$ between groups of the study at the stage of intubation.

line levels by an average of $26.5 \%(p=0.001)$ and $16.9 \%$ $(p=0.001)$, respectively, and without a significant difference between the groups $(p=0.207$ ) (Table II).

At the same time, already at the intubation stage, we observed a significant increase in HR compared to the induction stage in patients of group I by $29.6 \%(p=0.001)$, while in group II it only increased non-significantly $(p=0.703)$. Moreover, in patients of the first group, HR values were significantly higher by $16.3 \%(p=0.004)$ compared to patients of the second group (Table II, Figure 1).

At the stage of maintaining anesthesia, group I patients had a significant decrease in HR compared to the intubation stage by $21.9 \%(p=0.001)$ and by $25.6 \%$ compared to the baseline level. However, the HR values at the stage of maintaining anesthesia in patients of group II did not significantly differ from the intubation stage $(p=0.545)$ (Table II, Figure 1). At the stage of sternum reduction, the HR values in both study groups did not significantly differ from the initial level $(p=0.419$ and $p=0.601)$.

As we can see, changes in HR in patients of the first group were characterized by a significant amplitude of dynamics, while in patients of the second group, the average $H R$ values were relatively at the same level throughout the entire anesthesiological support.

Analyzing the dynamics of mean arterial pressure (MAP), we obtained similar results. Thus, at the induction stage, there was a significant decrease in MAP among both patients of the first and second groups by $32.4 \%$ ( $p=0.009 \%)$ and $8.0 \%(p=0.008)$, respectively, compared to the baseline level (Table II, Figure 2).

Further, at the intubation stage, there was a significant increase in this indicator by $25.9 \%(p=0.009)$ among patients within group I, and only a non-significant increase by $7.9 \%(p=0.016)$ among patients within group I compared to the induction stage was established (Table II, Figure 2). At the same time, the value of MAP in both groups of the study did not significantly differ from the initial level ( $p=0.641$ and $p=0.710$ ) (Table 2, Figure 2).

As for the dynamics of MAP at the stage of maintaining anesthesia, the patients of group I had a significant

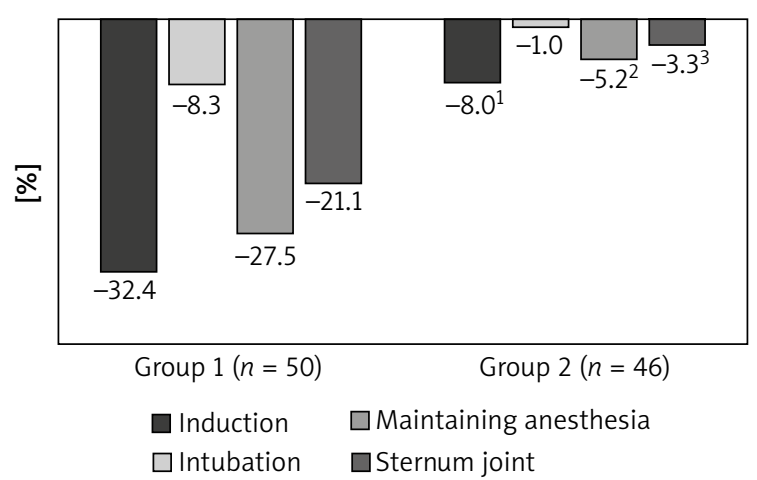

Figure 2. Dynamics of MAP at the stages of anesthesia using various schemes of anesthetic support, percentage of the initial level ${ }^{1} p=0.014$ between study groups at the induction stage, ${ }^{2} p=0.017$ between study groups at the support stage, ${ }^{3} p=0.02$ between study groups at the stage of sternum reduction.

decrease in this indicator by $27.5 \%(p=0.001)$, while the patients of group II had only a non-significant decrease by $5.2 \%(p=0.099)$ compared to the initial values (Table II, Figure 2).

Thus, MAP changes in group I during anesthetic management were characterized by a significant reduction at the stage of induction, support and sternum reduction, whereas in group II patients MAP values were relatively at the same level during the entire anesthetic management and significantly differed from baseline only in the induction phase of anesthesia (Table II, Figure 2).

Such changes are associated with the fact that the drugs used for introductory anesthesia reduced the sympathetic nervous system tone, and redistributed the circulating blood volume to the vascular network, which contributed to the preload reduction. In turn, a decreased filling of the heart ventricles led to less wall stretching of both left and right ventricles and consequently, according to the Frank-Starling mechanism, reduced cardiac output.

It should be noted that in both groups, relatively similar dynamics of PPI were observed (Table II) with growth at the induction stage maintaining the same level at the intubation stage, reaching maximum values at the anesthesia maintenance stage, and a significant decrease at the sternum reduction stage. This indicated the decrease in the peripheral vascular resistance level and required its correction with small doses of norepinephrine.

Also, at all stages of anesthetic support, there were no significant changes in the BIS level in comparison with previous values, or between the study groups, which indicates the proper effectiveness of the multimodal low-opioid anesthesia sedative component.

Performing artificial blood circulation and in the early postperfusion period, blood circulation indicators in all examined patients corresponded to the hemodynamic profile of the operated pathology.

None of the patients reported intraoperative events or complained of any side effects that could be associated with lidocaine use (arrhythmia, metallic taste, tinnitus, visual disturbances). 
The scales of comfort and pain in the early $\mathrm{p} / \mathrm{o}$ period did not differ statistically in the study groups, which indicated comparable and sufficient analgesia in the group of low-opioid anesthesia.

Also, the dynamics of mean values of cardiospecific enzymes in all patients corresponded to this surgical category, which indicated that the multimodal low-opioid anesthetic technique used in our study did not have negative effects on the myocardium and did not cause a coronaryconstrictive effect (Table III).

A comparative assessment of biochemical stress changes indicators was performed using various schemes of anesthetic support and showed that the performance of low-opioid anesthesia was characterized by $33.3 \pm 1.4 \%(p=0.0002)$ significantly lower levels of lactate $(1.4 \pm 0.5 \mathrm{mmol} / \mathrm{l})$ at the end of the operation compared with the use of routine doses of fentanyl $(2.1 \pm 0.9 \mathrm{mmol} / \mathrm{l})$. Also, the glucose level at the end of the operation was significantly lower by $20.5 \%$ $(p=0.0005)$ in group 2 than in group $1(7.0 \pm 2.0$ to 8.8 $\pm 2.1 \mathrm{mmol} / \mathrm{l})$. Immediately after surgery, the cortisol level in group II $(13.95 \pm 1.6 \mathrm{nmol} / \mathrm{ml})$ was within the reference values and significantly lower $-48.4 \pm 2.4 \%$ ( $p=0.000001)$ compared to group I $(20.70 \pm 3.26 \mathrm{nmol} / \mathrm{l})$, which indicated excessive activation of the adrenal cortex in response to surgery under anesthesia using routine doses of opioids.

\section{Discussion}

The conceptual approach to improve patient care, reducing p/o period complications, and comprehensive approach for early rehabilitation after surgery (ERAS) in modern surgery is widely welcomed. Extended ERAS protocols are multimodal perioperative treatment pathways that also include intraoperative use of short-acting anesthetics and limited opioid use, and the perioperative period has to provide effective analgesia [6].

Technically, this is extremely difficult due to highly traumatic operations in open heart surgery. As studies conducted in the United States and Norway have shown, 77-85\% of patients experience p/o pain within 2 weeks after heart surgery [7]. Therefore, opportunities to optimize and improve the quality of anesthesia (by reducing the dosage of opioids) have been progressively introduced into cardiac surgery in the past few years [8].

The works of many researchers have shown that opioids provide an initial analgesic effect, but then it reduces the pain threshold to a lower level than the initial one, which promotes the development of opioid-induced hyperalgesia. This leads to the necessity of frequent narcotic analgesic dose increases in the early p/o period [9]. The example of remifentanil by Hillman et al., showed that an increase in pain and the induction of mechanical hyperalgesia were observed after 30 minutes of its infusion at the dose of $0.05-0.1 \mathrm{~g} / \mathrm{kg} / \mathrm{min}[10]$.

In studies by Odunayo et al., a negative immunomodulatory effect of some opioids was noted [11] and even increased rates of cancer recurrence were found using narcotic analgesics [12]. In addition, as shown in the works
Table III. Dynamics of cardiospecific enzymes' mean values in the study group

\begin{tabular}{lcccc} 
Indicator & Output & $\begin{array}{c}8-12 \mathrm{p} / 0 \\
\text { hours }\end{array}$ & $\begin{array}{c}24-28 \mathrm{p} / 0 \\
\text { hours }\end{array}$ & $\begin{array}{c}36-40 \mathrm{p} / \mathrm{o} \\
\text { hours }\end{array}$ \\
$\mathrm{CPK}-\mathrm{MB}$ & $0.41 \pm 0.01$ & $0.48 \pm 0.01$ & $0.45 \pm 0.02$ & $0.43 \pm 0.01$ \\
\hline $\mathrm{TNI}$ & $1.44 \pm 0.01$ & $1.8 \pm 0.04$ & $1.6 \pm 0.02$ & $1.5 \pm 0.03$ \\
\hline
\end{tabular}

p/o - postoperative, CPK-MB - myocardial fraction of creatine phosphokinase, $\mathrm{TNI}$ - troponin I.

of Robertson et al., sleep disorders are more common in patients receiving opioids [13].

Moreover, excessive opioid prescribing has led to the "opioid crisis", which in turn has led to the number of necessary recommendations from the American Pain Society (APS) and the American Society of Anesthesiologists (ASA), in which the main focus was to offer multimodal analgesia or use of various painkillers, non-steroidal anti-inflammatory drugs (NSAIDs) as part of multimodal analgesia for the treatment of p/o pain [14].

Current research has shown that a lower dose of opioids has a positive effect on $\mathrm{p} / \mathrm{o}$ recovery in patients who have undergone cardiac surgery with $A B C$ [15], but further randomized studies are needed to confirm these results.

In this regard, non-narcotic analgesics, which are used in the scheme of multimodal low-opioid anesthesia, are of particular interest.

In the study of various protocols for opioid-free general anesthesia, Mauermann et al. analyzed the most commonly used non-narcotic analgesics, lidocaine and ketamine [16]. In the work of Peltoniemi et al., they stated that ketamine showed analgesic and opioid-sparing effects [17]. This is partly due to a decrease in central sensitization caused by the release of glutamate. The feasibility of ketamine introduced into the scheme is due to the fact that it is a direct antagonist of NMDA receptors, which blocks the central sensitization, and inhibits the activation of excitatory amino acids (such as glutamate). It is important to note that the use of subnarcotic doses of ketamine does not cause side effects, such as hallucinations [16].

Many studies have shown that intraoperative IV lidocaine administration provides a statistically significant positive effect on $\mathrm{p} / \mathrm{o}$ analgesia: it contributes to a potential reduction in overall opioid consumption; reduces the duration of intestinal paresis; has an anti-inflammatory effect; increases the cardioprotective effect of cardioplegia; reduces the risk of arrhythmias; reduces the risk of brain inflammation (neuroprotective effects) [18, 19]; reduces circulating inflammatory cytokines and prevents secondary hyperalgesia and central sensitization, and reduces patients' hospital stay [20].

IV lidocaine inhibits the release of glutamate from presynaptic terminals in neurons of the spinal cord, simultaneously hyperpolarizing postsynaptic neurons, shifting the membrane potential.

This decrease in excitability of spinal neurons may be one of the possible mechanisms for the analgesic effect of IV lidocaine administration in acute pain [21]. 
Guinot et al. noted that the non-opioid group of patients showed higher intraoperative use of antihypertensive agents. They used ketamine, dexamethasone, and lidocaine in their regimen [15]. In our study, we did not note such hemodynamic features in the indicated scheme of multimodal low-opioid anesthesia. On the contrary, the trend lines of patients differed in a stable hemodynamic line. The inclusion of dexketoprofen trometamol in the scheme reduces prostaglandin synthesis by inhibiting cyclooxygenase system (COX-1 and COX-2), thereby preventing the development of inflammation or reducing pain [22].

Thus, this study confirms the possibility of using multimodal low-opioid anesthesia during coronary artery bypass surgery with $A B C$.

\section{Conclusions}

Changes in HR within group I were characterized by a significant amplitude of dynamics. The average HR values within group II were relatively at the same level throughout the entire anesthetic provision. MAP changes in group I during anesthetic management were characterized by a significant reduction at the stage of induction, support and sternum reduction, whereas in group II the MAP value was relatively at the same level during the entire anesthetic management and significantly differed from baseline only at the stage of induction. In both study groups, similar dynamics of peripheral perfusion index (PPI) were observed with growth at the induction stage, maintaining the same level at the intubation stage, reaching maximum values at the anesthetic maintenance stage, and with a significant decrease at the sternal reduction stage. There were no significant changes in the level of BIS $(p>0.05)$ at all stages of anesthetic support in comparison with previous values, as well as between the study groups, which indicates the proper effectiveness of the sedative component of multimodal low-opioid anesthesia.

\section{Acknowledgments}

This work was supported solely by the Ministry of Health of Ukraine.

\section{Disclosure}

Part of this publication will be the medical thesis of scientific and experimental work of the P. L. Shupyk National Medical Academy of Postgraduate Education Department of Anesthesiology and Intensive Care: "Development of Organizational and Clinical Aspects of Improving Patients' Safety in Anesthesiology and Intensive Care".

The authors report no conflict of interest.

\section{References}

1. Naghavi M, Abajobir AA, Abbafati C, et al. Causes of Death Collaborators Global, regional, and national age-sex specific mortality for 264 causes of death, 1980-2016: a systematic analysis for the Global Burden of Disease Study 2016. Lancet 2017; 390: 1151-1210.

2. Wang $\mathrm{H}$, Naghavi M, Allen C, et al. Mortality and Causes of Death Collaborators. Global, regional, and national life expectancy, all-cause mortality, and cause-specific mortality for 249 causes of death, 1980-2015: a systematic analysis for the Global Burden of Disease Study 2015 Lancet 2016; 388: 1459-1544.

3. Roger VL, Go AS, Lloyd-Jones DM, et al. Heart disease and stroke statistics-2011 update: a report from the American Heart Association. Circulation 2011; 123: e18-e209.

4. Mannucci PM, Nobili A, Pasina L, et al. Polypharmacy in older people: lessons from 10 years of experience with the REPOSI register. Intern Emerg Med 2018; 13: 1191-1200.

5. Loskutov OA, Danchyna TA, Kolesnykov VG, et al. The first experience of using multimodal low-opioid anesthesia for coronary artery bypass surgery. J Emergency Med 2018; 89: 78-83.

6. Vukovic N, Dinic L. Enhanced recovery after surgery protocols in major urologic surgery. Front Med 2018; 5: 93.

7. Bjørnnes AK, Rustøen T, Lie I, et al. Pain characteristics and analgesic intake before and following cardiac surgery. Eur J Cardiovasc Nurs 2016; 15: 47-54.

8. Zubrzycki M, Liebold A, Skrabal C, et al. Assessment and pathophysiology of pain in cardiac surgery. J Pain Res 2018; 11: 1599-1611.

9. Funk RD, Hilliard P, Ramachandran SK. Perioperative opioid usage: avoiding adverse effects. Plast Reconstr Surg 2014; 134 (4 Suppl 2): S32-S39.

10. Hillman DR, Platt PR, Eastwood PR. Anesthesia, sleep, and upper airway collapsibility. Anesthesiol Clin 2010; 28: 443-455.

11. Odunayo A, Podam JR, Kerl MR. Immunomodulatory effects of opioids. J Vet Emerg Crit Care 2010; 20: 376-385.

12. Cata JP, Bugada D, Marchesini M. Opioids and cancer recurrence: a brief review of the literature. Can Cell Microenviron 2016; 3: 1159.

13. Robertson JA, Purple RJ, Cole P, et al. Sleep disturbance in patients taking opioid medication for chronic back pain. Anaesthesia 2016; 71: 1296-1307.

14. Chou R, Gordon DB, de Leon-Casasola OA, et al. Management of postoperative pain: a clinical practice guideline from the American Pain Society, the American Society of Regional Anesthesia and Pain Medicine, and the American Society of Anesthesiologists' Committee on Regional Anesthesia, Executive Committee, and Administrative Council. J Pain 2016; 17: 131-157.

15. Guinot P, Spitz A, Berthoud V, et al. Effect of opioid-free anaesthesia on postoperative period in cardiac surgery: a retrospective matched case-control study. BMC Anesthesiol 2019; 19: 136.

16. Mauermann E, Ruppen W, Bandschapp O. Different protocols used today to achieve total opioid-free general anesthesia without locoregional blocks. Best Pract Res Clin Anaesthesiol 2017; 31: 533-545.

17. Peltoniemi MA, Hagelberg NM, Olkkola KT, Saari TI. Ketamine: a review of clinical pharmacokinetics and pharmacodynamics in anesthesia and pain therapy. Clin Pharmacokinet 2016; 55: 1059-1077.

18. Klinger RY, Cooter M, Berger M, et al. Effect of intravenous lidocaine on the transcerebral inflammatory response during cardiac surgery: a randomizedcontrolled trial. Can J Anaesth J Can Anesth 2016; 63: 1223-1232.

19. Gholipour Baradari A, Habibi MR, Habibi V, Nouraei SM. Administration of lidocaine to prevent cognitive deficit in patients undergoing coronary artery bypass grafting and valve plasty: a systematic review and meta-analysis. Expert Rev Clin Pharmacol 2017; 10: 179-185.

20. Aronsohn J, Orner G, Palleschi G, Gerasimov M. Opioid-free total intravenous anesthesia with ketamine as part of an enhanced recovery protocol for bariatric surgery patients with sleep disordered breathing. J Clin Anesth 2019; 52: 65-66.

21. Kurabe M, Furue H, Kohno T. Intravenous administration of lidocaine directly acts on spinal dorsal horn and produces analgesic effect: an in vivo patchclamp analysis. Sci Rep 2017; 7: 46814.

22. López Navarro AÁ, Martínez Gómez MA, Gras Colomer E, et al. Physicochemical stability of binary admixtures of paracetamol and dexketoprofen-trometamol for patient-controlled analgesia use. Eur J Hosp Pharm 2019; 26: 308-313. 